\title{
POLITIK PENEGAKAN HAK ASASI MANUSIA PADA MASA TRANSISI DI INDONESIA
}

\author{
Halili \\ Jurusan Pendidikan Kewarganegaraan dan Hukum FIS UNY \\ halili@uny.ac.id
}

\begin{abstract}
This article was aimed at (1) discovering and constructing the political dynamics in formulating the Law of the Court of Human Rights; (2) analyzing its implication on the future of politic of Human Rights in Indonesia. This essay was a result of content analysis research with qualitative-comparative approach. The finding showed that (1) substantively, the formulation of Law No. 26 Year 2000 on Human Rights Court has fundamental weaknesses such as a partial adaptation of The Roma Statute, the course of human rights court was constructed weak by stating its authority only on investigation, whereas attorney General's Office authority on investigation lacks of detail prescription, deleting the responsibility of command such as those on the Rome Statute, etc. A lot of lacks indicate that the law was only an instrument of transitional authority. The 'toothless' law indicates the victory of the old regime in political battlement and tension with the new regime in reformation era. The politicization of handling of human rights violation before the release of the law of Court on which the Representative People Council has authority to propose but the decision maker is the President by Presidential Decree. 2) the political dynamic has an implication on two long term situations, hoarding impunity and the crises of human rights values.
\end{abstract}

Keywords: human right court, political dynamic, impunity, Dinamika Politik, Impunitas, and value crisis

\section{PENDAHULUAN}

Bekerjanya Hak Asasi Manusia (HAM) dalam regulasi demokratis tentang kehidupan politik dan hukum merupakan standar legitimasi negara-negara modern (Savic, 2011). Dalam iklim politik otoritarian di masa orde baru, nyaris tidak dimungkinkan penyusunan regulasi partisipatif dalam rangka pembangunan kehidupan politik dan hukum yang terbuka dan setara. Regulasi yang dikeluarkan pemerintah Orde Baru lebih sering hadir sebagai alat legitimasi perilaku pemerintah.

Demokratisasi Indonesia yang dimulai sejak tahun 1998, dalam perspektif HAM menjadi harapan bagi pelembagaan politik HAM dalam bentuk regulasi yang menjadi basis moral, politis, dan legal bagi operasionalisasi HAM dalam kehidupan riil bernegara. Secara aktual dan prospektif, pelembagaan politik HAM tersebut diidealkan berorientasi sebesar-besarnya pada pemenuhan hak-hak mendasar warga negara. Di samping itu, secara retrospektif ada tumpuan asa pengungkapan kebenaran dan pemulihan hak-hak korban dalam berbagai kasus pelanggaran HAM yang terjadi pada masa rezim otoriter Orde Baru. Jadi, selain dalam rangka membangun sistem yang lebih memungkinkan jaminan perlindungan HAM dalam jangka menengah dan panjang, demokrasi seyogianya dapat menegakkan keadilan transisi (transitional justice) bagi korban pelanggaran HAM. Sebab warisan masalah akut masa lalu yang harus diselesaikan oleh pemerintahan pasca Orde Baru, selain korupsi, juga persoalan HAM (Sparringa, 2010). 
Faktanya, hingga saat ini HAM tetaplah menjadi isu yang problematik sebab tidak kunjung mengemuka upaya serius penyelenggara Negara untuk menuntaskan warisan persoalan HAM, terutama pelanggaran-pelanggaran HAM masa lalu. Fenomena impunitas dalam berbagai pelanggaran HAM menjadi salah satu problem serius bangsa Indonesia. Ada keengganan politik untuk menuntaskan kasus-kasus pelanggaran HAM dan justru mengemuka fenomena penimbunan impunitas (Hendardi, 2010).

Dalam kerangka rule of law, peraturan perundang-undangan merupakan salah satu anatomi dalam instalasi politik HAM. Salah satu produk hukum (sekaligus produk politik) sangat penting dalam kerangka pemenuhan, penegakan dan penghormatan HAM adalah UU No. 26 tahun 2000 mengenai Pengadilan HAM. Tidak saja penting, Undang-Undang tersebut merefleksikan bagaimana sesungguhnya potret politik penegakan HAM di Indonesia setelah terjadi pergantian rezim.

Pergulatan kepentingan politik di balik perumusan beberapa UU di bidang HAM mulai dari penyusunan naskah akademik hingga pembahasan di Dewan Perwakilan Rakyat (DPR) sangat kuat terbaca. Dalam UU HAM misalnya, mengemuka pertarungan kepentingan pada isu apakah anggota Komisi Nasional Hak Asasi Manusia (Komnas HAM) harus sepenuhnya dari kalangan masyarakat sipil yang independen dari (kemungkinan) intervensi negara atau karena ia adalah komisi negara maka harus tetap melibatkan unsur negara.

Demikian halnya dengan UU Pengadilan HAM. Politisasi atas berbagai aspek UU No. 26 tahun 2000 tersebut terjadi, mulai dari aspek filosofis hingga aspek teknisredaksional. Terdapat banyak kelemahan fundamental dalam UU Pengadilan HAM. Kelemahan tersebut antara lain, pertama, kelemahan substansial dimana UU Pengadilan HAM merupakan adaptasi parsial dari Statuta Roma tentang Mahkamah Pidana Internasional/International Crime Court (ICC). Kedua, ketidaksempurnaan hukum acara Pengadilan HAM. Ketiga, penelikungan penerjemahan Statuta Roma yang berdampak pada pengaburan substansi pelanggaran HAM yang menjadi yurisdiksi Pengadilan HAM (Halili, 2010).

Fenomena tersebut menunjukkan kentalnya nuansa politik di balik UU Pengadilan HAM. Nuansa politik tersebut berpangkal dari, antara lain, perdebatan antara perspektif masyarakat sipil yang direpresentasikan oleh Lembaga Swadaya Masyarakat dan para aktivis HAM dengan perspektif negara yang diwakili oleh pemerintah atau pejabat negara dalam seluruh proses penyusunan UU Pengadilan HAM.

Salah satu entry point untuk menganalisis dinamika politik di balik perumusan UU Pengadilan HAM adalah dengan melihat posisi para elit di masa transisi demokrasi di Indonesia. Dalam perspektif para transitolog demokratisasi merupakan proses yang dipengaruhi oleh tindakan, strategi, dan pilihan tertentu dari elit politik yang bermanfaat bagi transisi demokratis. Sementara beberapa pilihan lainnya sebaliknya terhadap demokratisasi. Jadi, demokratisasi sebagian besar dipengaruhi oleh sekumpulan apa yang dilakukan oleh elit dan individu, dan bukan oleh rakyat pada umumnya. Tidak saja apa yang dilakukan, tapi juga kapan, dimana, dan bagaimana. Itu semua yang paling menentukan transisi dari sistem otoritarian ke sistem demokratis.

Dengan kacamata itu, bekerjanya politik penegakan HAM sesungguhnya ditentukan 
oleh pilihan-pilihan dan tindakan elit politik pada waktu merumuskan regulasi. Patut diduga kuat, ada pertarungan antara kepentingan elit lama dan elit baru dalam perumusan kedua UU tersebut. Hal itu terlihat misalnya dari eksistensi Pengadilan HAM di wilayah nasional dan adopsi parsial Statuta Roma dalam yurisdiksi Pengadilan HAM. Keduanya mengekspresikan keinginan untuk memberikan proteksi atas elit lama (Soeharto dan rezimnya) dari kemungkinan diadili melalui ICC atas kejahatan-kejahatan kemanusiaan yang telah dilakukannya pada saat memerintah.

Persoalan permainan elit dalam politik penegakan HAM kongruen dengan berbagai hasil penelitian sebelumnya tentang "sepak terjang" elit menjelang, selama, dan pasca demokratisasi Indonesia. Studi Demos tentang "Masalah-masalah dan Pilihanpilihan Demokratisasi di Indonesia" tahun 2004, menegaskan bahwa jalan perubahan menuju demokrasi pasca Orde Baru telah dibajak oleh sekelompok elite (Demos, 2004).

Di tengah sistem yang masih tetap korup, kelompok elite itu menjalankan kepentingan mereka melalui mekanisme dan prosedur "demokrasi". Dengan cara ini, mereka membuat transisi menuju demokrasi macet di tengah jalan.

Para pembajak tersebut terdiri dari perpaduan antara elite lama Orde Baru yang masih bercokol dalam "gerbong reformasi" dengan elite baru yang datang setelah orde itu tumbang. Para elit itu menjadi kekuatan baru di bidang ekonomi, birokrasi, dan militer, yang memegang peran menentukan. Mereka terdapat dalam berbagai lapisan supra dan infrastruktur politik: antara lain di parlemen, partai politik, serta berbagai asosiasi sipil, politik, bisnis, juga di tubuh birokrasi. Gerakan popular yang mendorong terjungkalnya Soeharto dari kekuasaannya merupakan fragmen pendek dalam demokratisasi Indonesia. Segera setelah itu, arah demokratisasi dengan berbagai implikasinya kemudian dikendalikan oleh elit-elit pembajak tersebut.

Dengan potret demikian, analisis politik penegakan HAM di masa transisi dapat dibaca dari pertarungan politik elitis yang terjadi dalam perumusan UU Pengadilan HAM. Siapa saja kelompok elit yang terlibat dalam perumusan UU tersebut. Apa saja pilihan-pilihan politik mereka dan mengapa pilihan-pilihan itu diambil. Bagaimana pilihan-pilihan tersebut dikontestasikan dalam perumusan UU Pengadilan HAM tersebut.

Studi atas pergulatan politik elitis dalam penyusunan konstruksi politik dan hukum HAM bermakna, paling tidak, dalam dua hal: pertama, evaluasi atas kongruensi dan koherensi politik HAM dengan demokratisasi yang sedang berlangsung, kedua, menganalisis sekaligus menata ulang politik HAM yang memungkinkan demokrasi menjadi mekanisme yang dapat mewujudkan keadilan transisional.

Tulisan ini akan mengambil fokus pada proses perumusan Undang-Undang Pengadilan HAM pada tahap pembahasan RUU-nya dalam sidang-sidang Dewan Permusyawaratan Rakyat (DPR) serta hasil perumusan menjadi UU. Studi ini mengungkap bagaimana dinamika politik dalam perumusan dan pembahasan Rancangan Undang-Undang Pengadilan HAM, serta menganalisis implikasi dinamika politik tersebut terhadap masa depan politik HAM di Indonesia. 


\section{METODE}

Metode yang digunakan dalam studi ini adalah content

analysis/analisis konten/analisis isi, dengan pendekatan kualitatif-komparatif. Sumber data yang digunakan dalam penelitian ini adalah jenis paper. Sumber data tersebut berupa dokumen-dokumen primer deklarasi dan dokumen sekunder seperti buku dan dokumen-dokumen lain yang memberikan data penunjang atas dokumen primer.

Dalam analisis konten data sudah tersedia dari sumber data tertentu. Dalam penelitian ini data yang dimaksud adalah data yang terdapat dalam dua jilid dokumen "Berita Acara Sidang DPR RI tentang Proses Perumusan dan Pembahasan Rancangan Undang-Undang Pengadilan HAM" yang berjumlah sekitar 1.500 halaman. Pengadaan data dilakukan dengan unitisasi dan pencatatan. Unitisasi dilakukan dengan penentuan unit referensi, unit sintaksis, dan unit tematik.

Instrumen yang digunakan dalam penelitian ini adalah peneliti sendiri dengan bantuan chek list dan recording note. Check list dan recording note tersebut digunakan untuk melacak dan merekam data. Pengujian keabsahan data menggunakan validitas semantik (untuk mengetahui ketepatan dalam mengartikan kata) dan prediktif (untuk mengetahui ketepatan memaknai data yang sudah dikelompokkan secara tematik). Analisis yang digunakan dalam penelitian analisis konten ini adalah analisis deskriptif dan analisis inferensial.

\section{HASIL DAN PEMBAHASAN}

\section{Kelemahan UU Pengadilan HAM}

Pada mulanya Undang-Undang (UU) No. 26 tahun 2000 tentang Pengadilan HAM dipandang sebagai bagian dari instrumen untuk memperkuat konstruksi bangunan HAM dalam tatanan demokrasi Indonesia Pasca Soeharto. Meskipun "tidak sempurna," undang-undang tersebut pada mulanya disambut gembira, karena diharapkan dapat menjadi payung hukum bagi penuntasan kasus-kasus pelanggaran HAM berat masa lalu melalui jalur meja hijau.

Pada perkembangan selanjutnya, UU tersebut disadari tidak memiliki implikasi apapun bagi penguatan penghormatan dan jaminan perlindungan HAM. Hal itu pada pokoknya disebabkan oleh kelemahan mendasar yang terdapat dalam UU dimaksud.

UU tersebut "mengadopsi" secara terbatas yurisdiksi Pengadilan Pidana Internasional (PPI) yang ditegaskan dalam Bagian 2 Statuta Roma, khususnya Pasal 5 sampai 8. Sebagaimana mafhum, yurisdiksi Mahkamah Pidana Internasional sesuai Statuta Roma meliputi empat kejahatan extraordinary, yaitu genosida, kejahatan terhadap kemanusiaan, kejahatan perang, dan kejahatan agresi.

Pelanggaran HAM berat yang menjadi yurisdiksi dari Pengadilan HAM hanya meliputi dua jenis kejahatan, yaitu genosida dan kejahatan terhadap kemanusiaan. Parsialitas adaptasi yang dilakukan merupakan salah satu kelemahan substansial yang sangat mendasar dari UU Pengadilan HAM. Pengabaian atas kejahatan perang dan kejahatan agresi menunjukkan politik hukum di balik UU Pengadilan HAM tidak sepenuhnya berdasar pada komitmen atas penegakan HAM.

Selain itu, kelemahan lain dari UU Pengadilan HAM adalah pada aspek hukum acara Secara garis besar, hukum acara Pengadilan HAM meliputi empat kewenangan utama, yakni penyelidikan, penyidikan (di dalamnya termasuk penangkapan dan penahanan untuk 
kepentingan penyidikan), penuntutan, dan pemeriksaan di pengadilan.

Penyelidikan terhadap pelanggaran HAM berat dilakukan oleh Komnas HAM dengan cara membentuk tim ad hoc yang terdiri atas Komisioner Komnas HAM dan unsur masyarakat (Pasal 18 UU No. 26 tahun 2000). Namun, kewenangan tersebut hanyalah proses awal yang merupakan kewenangan Komnas HAM dari seluruh proses panjang mengadili pelaku pelanggaran HAM berat. Bila Komnas HAM menemukan dugaan dan bukti awal terjadinya pelanggaran HAM berat sebagaimana menjadi yurisdiksi Pengadilan HAM, maka Komnas HAM melaporkannya untuk dilanjutkan ke tahapan acara selanjutnya, yaitu penyidikan.

Tahapan acara pengadilan HAM berupa penyidikan dan penuntutan berada di tangan Jaksa Agung. Dua kewenangan utama ini sebenarnya merupakan kewenangan kunci dari Pengadilan HAM. Di sinilah persoalannya. Sangat jelas, terdapat perbedaan background professional dan institusional antara Komnas HAM dan Kejaksaan Agung. Komnas HAM merupakan lembaga yang secara spesifik "bergelut" dengan persoalan perlindungan dan penegakan HAM. Namun, dengan kewenangan yang sangat kecil yang dimilikinya, kinerja Komnas HAM seringkali tidak berpengaruh besar bagi upaya penghukuman atas pelanggaran HAM. Pada praktiknya, terdapat perbedaan perspektif sangat mendasar atas sebuah pelanggaran HAM. Komnas HAM sesuai dengan expertise-nya seringkali menggunakan perspektif HAM bagi sebuah kejahatan extraordinary, sedangkan Kejaksaan Agung melihatnya dari kacamata hukum pidana biasa yang justru melemahkan efektivitas kinerja penyelidikan yang telah dilakukan oleh Komnas HAM sebelumnya. Tak hanya dengan Kejaksaan Agung, perbedaan cara pandang tersebut terjadi juga dengan para hakim yang melakukan pemeriksaan dalam proses peradilan.

Masalah tersebut terjadi karena UU Pengadilan HAM tidak disertai dengan peraturan khusus yang jelas dan detail mengenai prosedur hukum acara dalam rangka pengadilan HAM tersebut. Berbeda halnya dengan Statuta Roma. Statuta Roma dilengkapi dengan hukum acara khusus dan penjelasan unsur-unsur kejahatan yang menjadi yurisdiksi Mahkamah Pidana Internasional dalam dua peraturan yang dibuat terpisah, yakni Rules of Procedure and Evidence sebagai hukum acaranya, dan Element of Crimes sebagai penjelasan unsurunsur kejahatannya. Dua aturan tersebut memberikan pemahaman yang sama mengenai substansi sekaligus tata caranya kepada hakim dan aparat penegak hukum lainnya dalam rangka pengadilan pelakupelaku kejahatan yang menjadi yurisdiksi Mahkamah Pidana Internasional.

Selain itu, juga terjadi pelemahan signifikansi UU Pengadilan HAM, sebab semuanya kemudian dikembalikan kepada Pasal 10 yang berbunyi: "Dalam hal tidak ditentukan lain dalam undang-undang ini, hukum acara atas perkara pelanggaran hak asasi manusia yang berat dilakukan berdasarkan ketentuan hukum acara pidana."

Kelemahan lain dari UU Pengadilan HAM adalah penelikungan transliteratif atas prinsip-prinsip dan ketentuan mengenai kejahatan genosida dan kejahatan terhadap kemanusiaan yang diatur dalam Statuta Roma. Terdapat begitu banyak ketidakteraturan penggunaan padanan dan serapan Bahasa Indonesia dari ketentuan aslinya yang termuat dalam Statuta Roma 
(Smith, 2008)). Misalnya, frasa “...directed against civilian population...” diterjemahkan menjadi "ditujukan secara langsung terhadap penduduk sipil..." Adanya kata "secara langsung" dalam frasa tersebut berimplikasi terhadap terjadinya kesulitan untuk menjerat pelaku-pelaku pelanggaran yang bertindak tidak di lapangan (tidak langsung).

Di samping itu, dalam kejahatan terhadap kemanusiaan Pengadilan HAM tidak mencantumkan satu jenis kejahatan yang menjadi bagiannya dalam Statuta Roma, yaitu Pasal 7 huruf (k) yang berisi: "Tindakantindakan tidak berperikemanusiaan lain yang mempunyai sifat yang sama yang dengan sengaja menyebabkan penderitaan yang luar biasa atau luka yang serius terhadap kesehatan tubuh atau mental."

Tidak diadaptasinya bentuk kejahatan tersebut dalam kejahatan kemanusiaan versi Pengadilan HAM Indonesia akan menyebabkan tidak diakomodirnya bentukbentuk kejahatan terhadap kemanusiaan yang terus berkembang seiring dengan perkembangan ilmu pengetahuan manusia dan perangkat teknologi belakangan ini.

Ketidaksesuaian adaptasi UU Pengadilan HAM atas Statuta Roma juga terjadi dalam pengaturan mengenai tanggung jawab komando. Hal itu terlihat dalam Pasal 42, yang menggunakan kata "dapat" dan membuang frasa "secara pidana" sebagaimana yang dinyatakan dalam Pasal 28 Statuta Roma dengan frasa "shall be criminally responsible”, yang mestinya diserap dalam padanan bahasa Indonesia menjadi "harus bertanggungjawab secara pidana”. Ketentuan dalam UU Pengadilan HAM tersebut memberikan penegasan bahwa seorang komandan tidak harus selalu mempertanggungjawabkan secara pidana setiap tindakan bawahan di lapangan, sekalipun hal itu sebagai akibat ekoran dari komando yang telah diberikannya.

\section{Dinamika Politik Dalam Perumusan}

\section{Uu Pengadilan Ham}

Bahwa keberadaan UU No. 26 Tahun 2000 tentang Pengadilan HAM merupakan reaksi terhadap aspirasi dunia internasional yang ingin mengadili mereka yang dituduh melakukan kejahatan terhadap kemanusiaan di Timor Timur pasca jejak pendapat jelas tak dapat dipungkiri oleh siapapun. Sementara secara positif harus dikatakan bahwa keberadaan UU tersebut patut diapresiasi sebagai bukti bahwa Bangsa Indonesia berkehendak baik (good will) untuk menyelesaikan sendiri dugaan pelanggaran HAM melalui pengadilan HAM nasional.

Perlu mendapat catatan juga bahwa Pengadilan HAM di Indonesia merupakan mekanisme nasional pengadilan pelanggaran HAM berat satu-satunya di dunia. Setiap pelanggaran berat HAM (gross violation of human rights) merupakan yurisdiksi dari Mahkamah Pidana Internasional, sehingga pelanggaran demikian selalu dibawa untuk diselidiki dan diadili dalam mahkamah pidana di bawah yurisdiksi PBB tersebut. Oleh karena itu, berbagai pelanggaran HAM berat yang terjadi lazimnya diseret ke Mahkamah Pidana Internasional, seperti para pejabat tinggi Nazi Jerman, diktator Chile Augusto Pinochet, penjahat perang Yugoslavia Slobodan Milosevic, dan lain sebagainya.

Melihat parsialitas adaptasi sebagaimana dibahas dalam pembahasan di muka dapat dianalisis beberapa dinamika politik di dalam perumusan Undang-Undang Pengadilan HAM, antara lain: Pertama, ketegangan pertarungan elitis. Dalam pembahasan Undang-Undang Pengadilan HAM sangat tampak tarik menarik di level elit, yaitu antara elit lama dengan elit baru. Elit lama di sini 
dapat dilokalisasi pada mereka yang dibesarkan oleh Pemerintahan Soeharto dan memiliki kepentingan (interest) atau paling tidak, hasrat untuk melindungi Soeharto sebagai patronnya. Sedangkan elit baru adalah mereka yang lahir dari rahim autentik reformasi.

Sebagaimana kita tahu, salah satu dari enam tuntutan reformasi adalah "Pengadilan mantan presiden Soeharto dan kronikroninya" baik untuk berbagai kasus pelanggaran HAM, seperti Tanjung Priok, penembakan misterius, penculikan aktivis, dan sebagainya, maupun kasus-kasus korupsi yang terjadi dalam pemerintahannya. Dalam konteks wacana pengadilan mantan presiden Soeharto dalam kasus-kasus pelanggaran HAM, elit-elit lama yang masih berkuasa melalui kewenangan lembaga legislatif cenderung ingin melindungi Soeharto dari kemungkinan diseretnya Soeharto ke Mahkamah Pidana Internasional.

Perumusan UU Pengadilan HAM merupakan sebentuk kemenangan elit lama dalam kontestasi sikap politik elit lama versus elit baru dalam isu pengadilan mantan presiden Soeharto untuk berbagai pelanggaran HAM berat yang terjadi dalam pemerintahannya. Pengadilan HAM di tingkat nasional ini oleh dunia internasional dibaca sebagai itikad baik Indonesia untuk mengungkap kasus-kasus pelanggaran HAM masa lalu yang juga menjadi concern internasional. Hal itu terbukti dari semakin memudarnya perhatian dunia atas pelanggaran HAM di Indonesia pada masa lalu dan kemungkinan membawanya ke pengadilan HAM di tingkat internasional.

Secara faktual terbukti bahwa UU Pengadilan HAM merupakan mekanisme yang tidak pernah secara serius digunakan sebagai mekanisme nasional untuk mengadili pelanggaran-pelanggaran HAM yang terjadi, baik di masa lalu maupun setelah diundangkannya UU Nomor 26 tahun 2000. Hingga meninggalnya Soeharto bahkan hingga 15 tahun pasca reformasi tidak tampak intensi pemerintah untuk melakukan proses penegakan hukum atas pelanggaranpelanggaran HAM berat di Indonesia.

Kedua, politisasi pelanggaran HAM. Di samping tarik-menarik politis elit lama versus elit baru secara formal-prosedural, secara substantif UU Pengadilan HAM juga melakukan politisasi pelanggaran HAM masa lalu, atau sebelum diundangkannya UU Pengadilan HAM. Pasal 43-yang terdiri dari tiga ayat itu memberi ruang keterlibatan Dewan Perwakilan Rakyat sebagai yang berhak mengusulkan pembentukan Pengadilan HAM ad hoc. Untuk pelanggaran HAM berat masa lalu, kewenangan penyelidikan yang diberikan UU kepada Komnas HAM dapat dianulir oleh intervensi politik DPR yang menentukan perlu tidaknya Pengadilan HAM ad hoc. Penjelasan Pasal 43 ini membatasi kewenangan penyelidikan oleh Komnas HAM dengan locus delicti dan tempus delicti tertentu. Pembatasan ini dan politisasi Pengadilan HAM ad hoc atas pelanggaran HAM masa lalu melalui keterlibatan "politisi" Parlemen justru membuka kemungkinan terjadinya "politik dagang sapi" dalam proses penghukuman atas terjadinya pelanggaran HAM.

\section{Implikasi Dinamika Politik Tersebut Terhadap Masa Depan Politik HAM Di Indonesia}

"Politisasi" dalam perumusan salah satu instrumen HAM nasional berupa UU No 26 Tahun 2006 tentang Pengadilan HAM pada akhirnya berimplikasi pada, paling tidak, dua situasi berikut. 
Pertama, penimbunan impunitas. Orentlicher (dalam Meijer, 2005) mendefinisikan impunitas sebagai "...ketidakmungkinan, de jure atau de facto dalam membawa para pelaku pelanggaran HAM untuk mempertanggungjawabkan tindakan yang mungkin menjadikan mereka bisa didakwa, ditangkap, diadili dan-jika ditemukan bersalah, dihukum dengan penghukuman yang tepat, dan untuk memberikan reparasi bagi para korban kejahatan mereka."

Dalam pandangan Orentlicher, impunitas muncul dari kegagalan negara memenuhi kewajibannya untuk melakukan investigasi atas pelanggaran HAM dan untuk mengambil langkah-langkah dan tindakan yang tepat terhadap para pelaku, khususnya dalam bidang hukum, dan para korban serta mencegah keberulangan dari kejahatan tersebut.

Dalam kaitan dengan fenomena impunitas, keberadaan UU No 26 Tahun 2000 tentang Pengadilan HAM tidak berdampak signifikan terhadap penghapusan impunitas, bahkan tidak berhasil membongkar impunitas dalam kasus pelanggaran-pelanggaran HAM berat sebelum maupun setelah 2000. Sejak diundangkannya UU Pengadilan HAM pada era Pemerintahan Abdurrahman Wahid paling tidak telah sembilan kasus yang telah diselidiki oleh Komnas HAM, dan menurut laporan Komisi diduga terjadi pelanggaran HAM berat pada kasus-kasus tersebut. Peristiwa-peristiwa yang telah diselidiki oleh Komnas adalah Tragedi Tanjung Priok (1984), Peristiwa Kerusuhan Semanggi Mei (1998), Peristiwa Trisakti (1998), Peristiwa Semanggi I (1998), Peristiwa Semanggi II (1999), Peristiwa Timor Timur (1999), Peristiwa Abepura (2000), Peristiwa Wasior (2001-2002), serta Peristiwa Wamena (2003).
Sebagai follow up atas penyelidikan yang telah dilakukan oleh Komnas HAM telah dibentuk dua Pengadilan HAM Ad Hoc, yaitu untuk Peristiwa Tanjung Priok tahun 1984 dan Peristiwa Kerusuhan Pasca Jajak Pendapat di Timor Timur tahun 1999. Satusatunya Pengadilan HAM permanen yang diselenggarakan berdasarkan UU No. 26 tahun 2000 adalah Pengadilan HAM di Makassar untuk mengadili pelaku-pelaku yang diduga melakukan pelanggaran HAM di Abepura. Pengadilan tersebut diselenggarakan menindaklanjuti laporan KPP HAM Abepura tahun 2000.

Hasilnya, hampir seluruh pengadilan yang berlangsung berakhir dengan dibebaskannya tersangka pelaku pelanggaran HAM tersebut. Kecuali Eurico Guteres yang sempat mendekam di LP Cipinang setelah divonis bersalah oleh Pengadilan HAM ad Hoc Kerusuhan Pasca Jajak Pendapat di Timor Timur, meskipun akhirnya dibebaskan oleh Mahkamah Agung pada tingkat kasasi.

Meskipun Pengadilan HAM secara formal telah 13 tahun yang lalu yurisdiksinya diatur melalui UU No. 26 tahun 2000, namun sampai saat ini belum ada pelanggaran HAM yang berhasil dijerat. Pelanggaran HAM berat yang direkomendasikan oleh Komnas HAM (paling tidak sembilan kasus yang dinyatakan di muka) dan disitir oleh berbagai media dan komunitas internasional sampai detik ini direkognisi berlangsung tanpa pelaku. UU Pengadilan HAM gagal menjadi sistem hukum HAM yang menjamin pengungkapan, penghukuman, dan pemidanaan pelanggaran HAM berat.

Realitas ini berbeda dengan berbagai fenomena internasional dimana hadirnya instrumen dan mekanisme international legal law telah dengan sangat signifikan menurunkan tingkat pelanggaran HAM 
sangat serius seperti yang berlangsung pada tahun 1990-an serta meningkatkan penghukuman terhadap pelaku-pelaku pelanggaran HAM sangat serius tersebut. Pengadilan HAM di Indonesia belum terbukti berhasil memberikan efek jera (deterrence effect). Fakta ini mengamini apa yang disebut sebagai faktor legal yang melanggengkan impunitas.

Kedua, krisis nilai HAM. Krisis nilai HAM yang terjadi pasca diundangkannya UU No 26 Tahun 2006 semakin dalam. Krisis nilai yang dimaksud adalah situasi dimana nilai-nilai HAM yang diambil kebajikankebajikan dan kemanusiaan universal semakin tergerus dalam mengontrol perilaku penyelenggara negara.

Sebagaimana kita ketahui, HAM merupakan sekumpulan hak dasar yang bersifat inheren dengan manusia karena kodrat mereka sebagai manusia. HAM juga berkaitan atau bahkan merupakan bagian pokok dari harkat dan martabat manusia (human dignity). Dengan demikian, nilai-nilai HAM merupakan nilai luhur yang levelnya barangkali seluhur manusia itu sendiri. Maka upaya untuk menjadikan HAM sebagai permainan politik demi menyelamatkan patron politik tertentu akan membawa HAM pada krisis nilai, dimana sekumpulan nilainilai bajik di dalamnya telah diperalat oleh penyelenggara negara untuk kepentingankepentingan politik sesaat.

Dalam konteks kelembagaan negara, HAM merupakan core content dalam konstitusi negara, sebagaimana lazim terjadi dalam konstitusi-konstitusi negara modern. Dengan demikian kerangka jaminan konstitusional negara demokrasi modern pada dasarnya merupakan mekanisme untuk pemenuhan, penghormatan, dan perlindungan HAM.
Krisis nilai HAM menunjukkan pengabaian pemerintah atau pejabat penyelenggara negara terhadap pelanggaran HAM yang terjadi. Pengabaian demikian berarti juga melakukan pengabaian atas ketentuan Undang-Undang Dasar Negara Republik Indonesia tahun 1945, terutama Pasal 28A sampai Pasal 28J. Jika situasi ini berlangsung secara terus menerus maka akan lahir situasi anomali dan anomik, dimana prinsip-prinsip, nilai-nilai, dan bahkan jaminan konstitusional HAM hanya akan indah di atas kertas tetapi hampa di dalam tindakan dan kenyataan.

\section{SIMPULAN}

Dari pembahasan terdahulu dapat ditarik kesimpulan sesuai dengan rumusan penelitian ini: Pertama. Secara substantif, perumusan Undang-Undang Nomor 26 Tahun 2000 Tentang Pengadilan HAM memuat beberapa kelemahan fundamental, antara lain adaptasi parsial tentang yurisdiksi Pengadilan HAM dari Statuta Roma, hukum acara Pengadilan HAM yang secara sengaja dikonstruksi lemah dengan menempatkan Komnas HAM hanya berwenang di tahap penyelidikan, sementara penyidikan oleh Kejaksaan Agung, tanpa regulasi lebih derivat dan detail mengenai hal itu, penghilangan pertanggungjawaban komando seperti yang diatur dalam Statuta Roma, dan sebagainya. Banyaknya kelemahan fundamental menunjukkan bahwa Undang-Undang ini hanyalah instrumen politis penyelenggara negara pada masa transisi. Rumusan UU HAM yang "tak bertaring" ini menunjukkan kemenangan elit lama dalam ketegangan dan kontestasi politik dengan elit politik baru era reformasi. Politisasi juga terjadi dalam penanganan pelanggaran HAM berat sebelum diundangkannya UU Pengadilan, yang 
menempatkan DPR memiliki kewenangan mengusulkan, sedangkan Presiden kewenangan memutuskan dalam bentuk Kepres.

Kedua. Dinamika politik demikian berimplikasi pada dua situasi jangka panjang; pertama, penimbunan impunitas. keberadaan UU No 26 Tahun 2000 tentang Pengadilan HAM tidak berdampak signifikan terhadap penghapusan impunitas, bahkan tidak berhasil membongkar impunitas dalam kasus pelanggaran-pelanggaran HAM berat sebelum maupun setelah 2000. Kedua, krisis nilai HAM. HAM merupakan sekumpulan hak dasar yang bersifat inheren dengan manusia karena kodrat mereka sebagai manusia. HAM juga berkaitan atau bahkan merupakan bagian pokok dari harkat dan martabat manusia (human dignity). Maka upaya untuk menjadikan HAM sebagai permainan politik demi menyelamatkan patron politik tertentu akan membawa HAM pada krisis nilai, dimana sekumpulan nilainilai bajik di dalamnya telah diperalat oleh penyelenggara negara untuk kepentingankepentingan politik sesaat.

\section{DAFTAR PUSTAKA}

Demos. (2004). Transisi demokrasi telah dibajak. Jakarta: Demos.

Halili. (2010). Pengadilan ham dan pelanggengan budaya impunitas. Jurnal Civics.

Hendardi. (2010, Mei 12). Menimbun impunitas. Kompas, 6.

Savic, O. (2011, Maret 18). The politics of human rights. Retrieved from http://usm.maine.edu/ bcj/issues/thre e/preface.html

Smith, R. K. (2008). Hukum hak asasi manusia. Yogyakarta: Pusat Studi HAM UII.

Sparringa, D. (2010, January 28). Wawancara Tahun 20004. Retrieved from http://www.kompas.co.id/kompascetak/0402/07/Politikhukum/842339 